\title{
THE DEVELOPMENT OF THE HYPOPHYSIS OF AMIA CALVA
}

\author{
P. E. SMITH \\ From the Hearst Anatomical Laboratory, University of California \\ TEN FIGURES
}

HYPOPHYSIS OF AMIA

The origin of the hypophysis in the various forms studied has been a source of disagreement, both in observation and in interpretation. The majority of those who have worked upon this question consider that the hypophysis arises from ectoderm; however, a few well known observers, Kupffer ('94), Valenti (in a series of papers), Nusbaum ('96), and Gregory ('02) state that it has also an entodermal contribution. The only author who describes the hypophysis as entirely entodermal in origin is Prather ('00) in Amia. That such an interesting phylogenetic anomaly is described seemed to the writer to warrant a further examination of this form, especially as Dean ('96) described this structure in this form, as of epiblastic origin.

The various specimens studied range in age from soon after the closure of the neural tube up to an $18 \mathrm{~mm}$. stage. In fixation and staining especial care was taken to preserve the yolk granules and cell boundaries so that these most valuable structural features would be retained. The ages could be determined only by comparison with the excellent figures of Dean ('96).

Figure 1 is from a median sagittal section of an embryo surrounding about $225^{\circ}$ of the yolk. It corresponds to the stage figured by Dean (fig. 2) and so is about 142 hours old, or the same age as the specimen figured by Prather (fig. 1). Beneath the hypothalamic region of the brain is the foregut and the stomo- 
daeum separated by an imperfectly formed oral plate. The ectoderm forming the floor of the stomodaeum differs somewhat from that of the roof. That of the floor is two layers in thickness having a more acidophilic cuticular layer and a more basophilic basal layer. The ectoderm of the roof has an imperfectly formed cuticular layer, and a definite, cytoplasmic-rich basal layer, while between the two is an irregular single or double layer of cells rich in yolk and not easily distinguished from the entoderm cells at the juncture of the stomodaeum with the foregut.

A growth of this basal layer caudad extends from both the floor and the roof of the stomodaeum. That from the floor contributes to the dental ledges while that from the roof is more extensive and is the hypophysial rudiment. The cells composing this mass are more protoplasmic than the entoderm cells which have many large yolk granules. Their cell boundaries are also more distinct than those of the entoderm cells. There is no limiting membrane between the entoderm and this hypophysial rudiment, at this or later stages, but in specimens properly stained and differentiated the two varieties of cells can easily be distinguished from each other. A strand of cells connecting the hypophysis to the basal layer of the ectoderm is present. This connecting strand was evidently overlooked by Prather, for he describes and figures (fig. 3) at a little later stage (160 hours) and in a position farther caudad, a nest of cells of this character. His figure also strongly suggests that his hypophysial rudiment is

\section{ABBREVIATIONS}

b.v., blood vesseı
ect., ectoderm
ect.m., basal layer of ectoderm
end., entoderm
end.d., entoderm, deep layer
end.s., entoderm, superficial layer
f.g., fore gut
hyp., hypophysis
inf., infundibulum
l., limit between ectoderm and ento-
$\quad$ derm

b.v., blood vesseı

ect., ectoderm

ect.m., basal layer of ectoderm

end., entoderm

end.d., entoderm, deep layer

end.s., entoderm, superficial layer

hyp., hypophysis

inf., infundibulum

derm

\author{
l.t., lamina terminalis \\ mes., mesenchyme \\ m.r., mamillary recess \\ op.c., optic commissure complex \\ op., optic chiasma \\ pr.s., premandibular somite \\ r.p.op., recessus post opticus \\ r.pr.op., recessus preopticus \\ st., stomodaeum \\ s.v., saccus vasculosus \\ v.l., vestigeal lumen
}



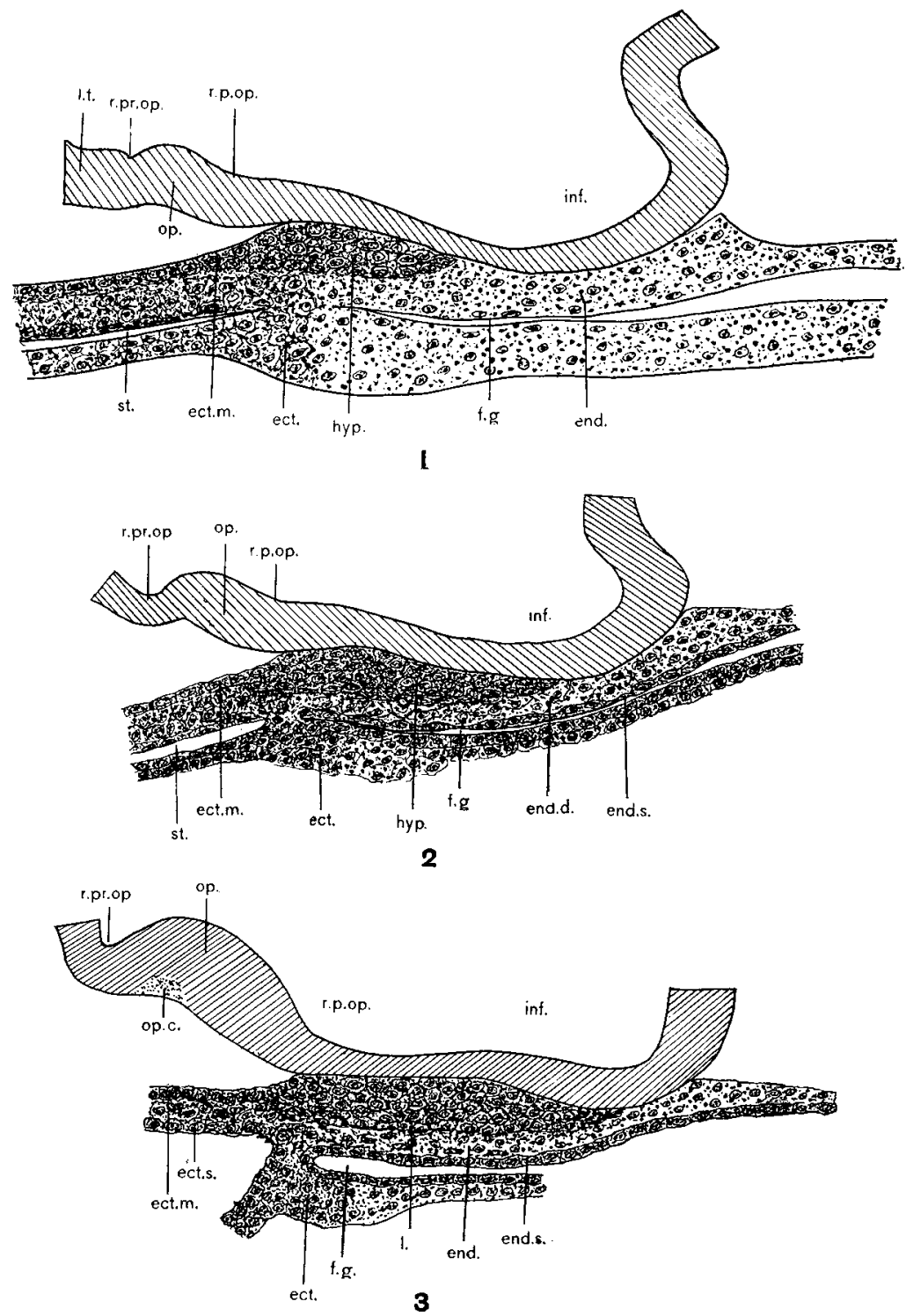

Fig. 1 A median sagittal section of a larva surrounding $220^{\circ}$ of the yolk; estimated age, 142 hours. $\times 200$.

Fig. 2 A median sagittal section of an embryo surrounding $290^{\circ}$ of the yolk; estimated age, 160 hours. $\times 200$.

Fig. 3 A median sagittal section of an embryo at the time of hatching. $\times 200$. 
connected to the ectoderm. In cross-section this cell mass appears as a single ovoid nest composed of both flattened and oval shaped cells.

In a later stage (fig. 2) corresponding to Dean's figure 5, larva surrounding $290^{\circ}$ of yolk, this cell mass can be still more easily distinguished from the entoderm. It has extended farther caudad and is separated from the cuticular layer of the entoderm by an irregular double layer of yolk laden cells. The connecting strand is still very evident.

Still older specimens (figs. 3, 4, 5) shortly after hatching, show that further growth of this structure has taken place but the relations remain unaltered. In figure 4 the deeper, yolk rich, layer of entoderm shows particularly well. Directly beneath the hypophysis, to an extent, but particularly at the sides the entodermal cells have become flattened, and to them especial attention will be called later. In figure 5, two sections cephalad to figure 4 , these entodermal cells are still more flattened.

In a $6 \mathrm{~mm}$. specimen (figs. 6,7 ) the hypophysis has assumed nearly its adult position. In the dorsal and lateral portions the cells are either oval or round, and show a radial arrangement towards a minute cavity, the vestigeal lumen. Ventral to the lumen the cells are few in number, flattened, and do not radiate towards the cavity. It is to the juncture of these flattened, ectodermal, hypophysial cells with the entoderm, that particular attention is directed. In the early stages of the hypophysis they were easily distinguished from the entoderm of the foregut. During development, however, the entoderm has been losing more and more of its yolk granules until its appearance is practically like that of the hypophysis, and so from this stage on these

Fig. I Cross-section through the cephalic portion of the hypophysis of an embryo at the time of hatching. $\times 200$.

Fig. 5 same series as figure 4 ; two sections caudad. $\times 200$.

Fig. (6) A median sagittal section of a $6 \mathrm{~mm}$. specimen. $\times 200$.

Fig. 7 Cross-section of a slightly older specimen. $\times 200$.

Fig. 8 A median sagittal section of an $8 \mathrm{~mm}$. specimen. $\times 200$.

Fig. 9 A median sagittal section of an $8 \frac{1}{2} \mathrm{~mm}$. specimen. $\times 200$.

Fig. 10 A median sagittal section of a $10 \mathrm{~mm}$. specimen. $\times 200$. 

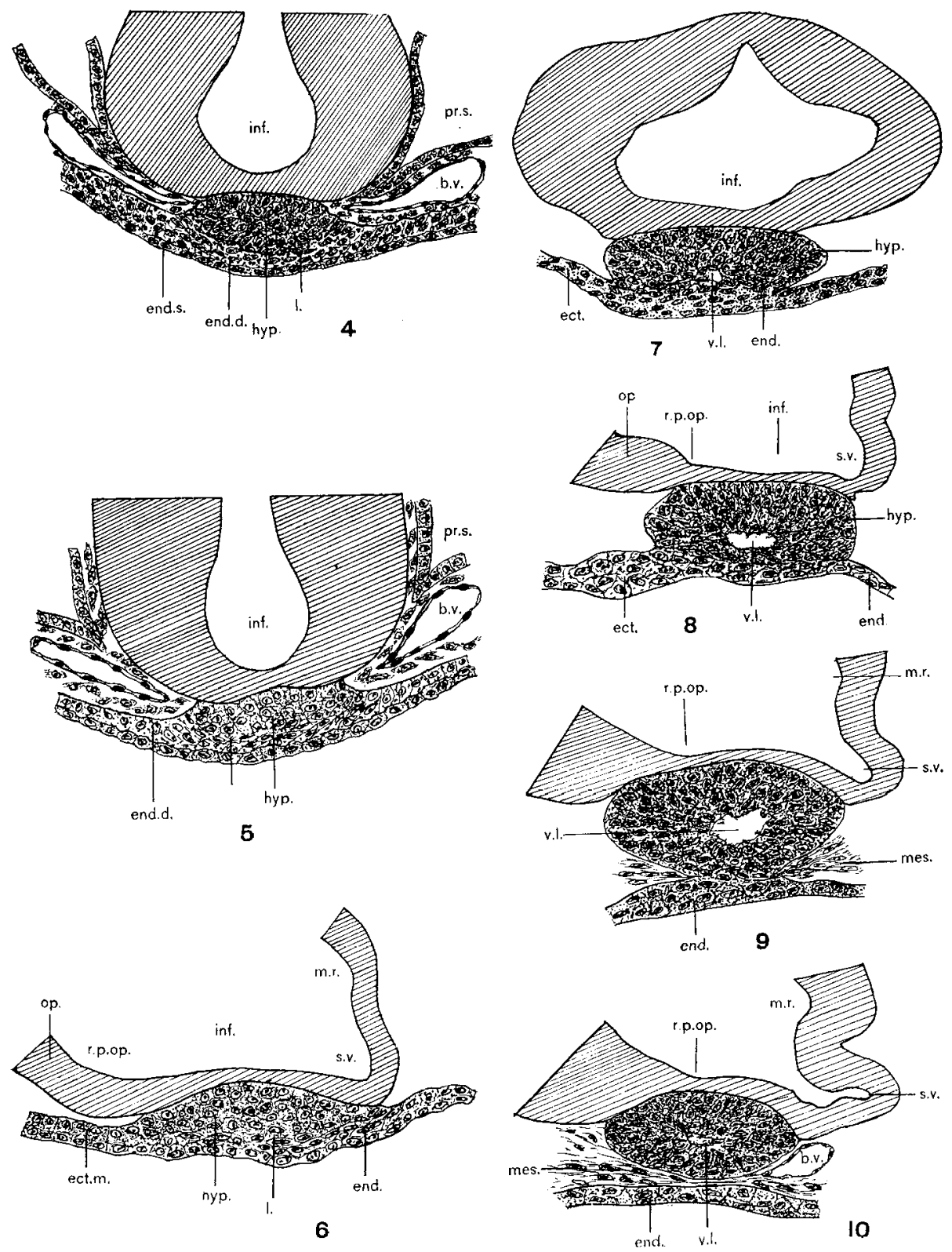
entodermal cells must be identified largely by their position In a cross-section of this age (fig. 7) the same condition is evident.

Later stages (fig. $8,8 \mathrm{~mm}$.; fig. $9,8 \frac{1}{2} \mathrm{~mm}$.) show the separation of the hypophysis from the pharynx. This separation takes place by or becomes apparent with a mesodermal ingrowth into the intercellular clefts at the sides and base of the hypophysis. Examination of sections at this critical stage shows convincingly that part of the flattened cells of the deeper layer of the entoderm become separated from the pharynx and enter into the formation of the hypophysis. Tracing these entodermal cells which border the ectodermal hypophysial rudiment, through the successive stages, has been the most interesting and difficult part of the study. At the time of the separation of the hypophysis from the mouth they can not be determined, structurally, from the cells of ectodermal origin. It is only by identifying them at the latest possible stage by their staining reaction and then by their position and relation that it can be said with considerable probability that they do enter into the formation of the adult hypophysis. The process is much like that described by Gregory ('02). In his figures (figs. 29, 30, 31) he indicates a flattening of the entodermal cells and their inclusion into the ectodermal hypophysial rudiment. However, he carries the process much further than here described and includes all the thickened entodermal mass caudad of the ectodermal hypophysial anlage in the formation of this structure. The difficulty of determining the limit between ectoderm and entoderm in Amia was also mentioned by Dean.

The vestigeal lumen has been well described by Prather and needs little additional attention. I limiting membrane as definite as he indicated was not noted. Extending away from the lumen are many intercellular spaces. It appears as if by secretion the cells force themselves apart. This is even more apparent later with the increase in the lobulation of the gland and the communication of the cavities of the various lobes with each other by intercellular spaces. 


\section{SUMMARY}

The development of the hypophysis in the ganoids has been worked out with rather uncertain results. Haller ('98) has cast doubt upon the work of von. Kupffer; Balfour and Parker ('82) were in doubt as to their own results; while Dean differs from Prather in the work upon Amia. This confusion is partially due, perhaps, to the developing adhesive organ, but primarily to the difficulty of distinguishing between the ectoderm and the entoderm. Their union is intimate from the first appearance of the hypophysis, and it is only by noting from the first the caudal growth of the basal layer of the ectoderm to form the hypophysial rudiment, that the origin of this gland can be given. The process in Amia differs in no essentials from that in the other teleosts and the amphibia. The relation of the entoderm of the foregut to the gland is of interest in showing the plasticity of the tissues. This adaptability of tissue or germ layers is especially well exemplified in the formation of the hypophysis in this form where the union of two germ layers is particularly close. As observed by the author in some other forms as well, the contiguity of the entoderm to the gland leads to the modification of the former and a change from its normal function to that of another germ layer. Whether this is due to the influence of the nervous system, the inherent tendency of the tissue, or some other factor or factors, cannot be stated at this time.

\section{LITERATURE CITED}

Balfour, F. M. and PArker, W. N. 1882 On the structure and development of I.epidosteus. Trans Roy. Soc., Part II.

Dean, B. 1896 On the larval development of Amia calva. Zoöl. Jahrb., Bd. 9.

Gregory, E. H. 1902 Beiträge zur Entwickelungsgeschichte der Knochenfische. Anat. Hefte, Bd. 20.

Haller, B 1898 Untersuchungen über die Hypophyse und die Infundibularorgane. Morph. Jahrb., Bd. 25.

Kingsufy, J. S., and Thyng, F. W. 1905 The hypophysis in Amblystoma. Tufts College Studies, No. 8. 
von Kupfare, C. 1893 Entwickelungsgeschichte des Kopfes. Ergeb. Anat. u. Entwick., Bd, 2.

1894 Die Deutung des Hirn Anhanges. Sitzber. Gesellsch. f. Morph., München.

Nusbaum, J. 1896 Einige neue Thatsachen zur Entwickelungsgeschichte der Hypophysis cerebri bei Säugetieren. Anat. Anz., Bd. 12.

Prather, J. M. 1900 The early stages in the development of the hypophysis of Amia calva. Biol. Bull., vol. 1.

Truney, F. 1911 Contribution to the study of the hypophysis cerebri with. especial reference to its comparative histology. Wistar Inst. Anat. and Biol., Memoir no. 2. 